\title{
Palladium-catalyzed regio- and stereoselective synthesis of aryl and 3-indolyl-substituted 4-methylene- 3,4-dihydroisoquinolin-1(2H)-ones
}

\author{
Valeria Nori ${ }^{1}$, Antonio Arcadi ${ }^{1}$, Armando Carlone ${ }^{1}$, Fabio Marinelli ${ }^{* 1}$ and Marco Chiarini ${ }^{2}$
}

\section{Full Research Paper}

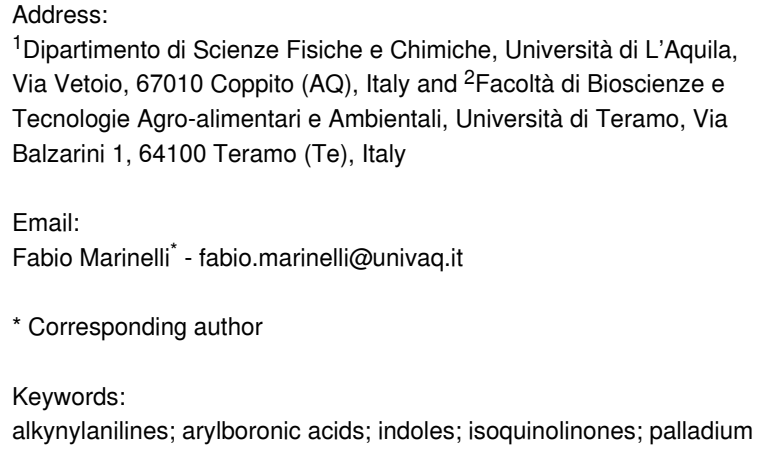

${ }^{1}$ Dipartimento di Scienze Fisiche e Chimiche, Università di L'Aquila Via Vetoio, 67010 Coppito (AQ), Italy and ${ }^{2}$ Facoltà di Bioscienze e Tecnologie Agro-alimentari e Ambientali, Università di Teramo, Via Balzarini 1, 64100 Teramo (Te), Italy

Beilstein J. Org. Chem. 2020, 16, 1084-1091. doi:10.3762/bjoc. 16.95

Received: 13 January 2020

Accepted: 05 May 2020

Published: 20 May 2020

Associate Editor: M. Rueping

(C) 2020 Nori et al.; licensee Beilstein-Institut. License and terms: see end of document.

\begin{abstract}
Cascade cyclocarbopalladation of the readily available aryl/alkyl-substituted propargylic amides containing an aryl iodide moiety, followed by Suzuki-Miyaura coupling with arylboronic acids, allowed an efficient regio- and stereoselective synthesis of tetrasubstituted 4-methylene-3,4-dihydroisoquinolin-1(2H)-ones. Moreover, cascade cyclocarbopalladation, followed by the reaction with 2-alkynyltrifluoroacetanilides, accomplished a double cyclization to afford challenging 4-methylene-3,4-dihydroisoquinolin$1(2 H)$-ones bearing a 3-indolyl substituent through aminopalladation/reductive elimination.
\end{abstract}

\section{Introduction}

The isoquinolinone nucleus is a key constituent of many natural products [1-3] and pharmaceuticals [4-6]. Substituted isoquinolinones have been found in biologically active small molecules that exhibit antihypertensive activity [7,8]. Moreover, these heterocycles can be used as 5-HT3 antagonists [9], rho kinase inhibitors [10], thymidylate synthetase inhibitors [11] PARP-1 inhibitors [12], melatonin $\mathrm{MT}_{1}$ and $\mathrm{MT}_{2}$ receptor agonist [13], and fascin-targeted antimetastatic agents [14] Fittingly, the development of efficient strategies for their construction and peripheral functionalization represents still an active research area aimed to achieve structural diversity [15$18]$.

Carbometalations of alkynes constitute a powerful tool for the regio- and stereoselective formation of carbon-carbon bonds [19]. Intramolecular palladium-catalyzed versions are particularly attractive, since they afford polycarbo- and heterocyclic systems via sequential reactions of the vinylpalladium intermediate [20-25]. In this field, a variety of regio- and stereoselective Pd-catalyzed cascade reactions, consisting of the addition 
of in situ-generated arylpalladium complexes over a proximate carbon-carbon triple bond, followed by cross-coupling reactions, have been reported [26-31].

Our continuing interest in the palladium-catalyzed reactions of functionalized alkynes with boronic acids [32,33] prompted us to explore the palladium-catalyzed reaction of the readily available alkynyliodobenzamides $\mathbf{2}$ with boronic acids $\mathbf{3}$ as a viable route to the regio- and stereoselective synthesis of 4-alkylidene-3,4-dihydroisoquinolin-1(2H)-ones 3 (Scheme 1a).

We are pleased to report here that this cascade reaction takes place efficiently, resulting in the regio- and stereoselective formation of the poly-substituted isoquinolinones $\mathbf{4}$ in good to high yield. Applications of this reaction can be relevant for improvements of structure diversity and fine tuning of the chemical and physical properties of the products.

Furthermore, over the years, we have reported a general methodology for the Pd-catalyzed synthesis of 3-substituted indoles, now referred to as the "Cacchi reaction" [34], through an aminopalladation/reductive elimination sequence starting from 2-alkynyltrifluoroacetanilides. In all these procedures, the activation of the triple bond was achieved by means of a $\sigma$-organyl palladium complex, in turn generated in situ by oxidative addition of a $\operatorname{Pd}(0)$ species to suitable organic electrophiles (aryl and vinyl halides or triflates [35,36], alkyl halides [37], alkynyl halides [38], $\alpha$-iodoenones [39], or by transmetalation of a $\mathrm{Pd}(\mathrm{II})$ species with boronic acids [33]. In this context, we decided to explore the use of substrates 2 in the reaction with 2-alkynyltrifluoroacetanilides $\mathbf{5}$ through a sequential cyclocarbopalladation/aminopalladation/reductive elimination process, widening in such a way the scope of the methodology and allowing challenging synthesis of indoles 6 bearing a 4-alkylidene-3,4-dihydroisoquinolin-1(2H)-one substituent (Scheme 1b). It is worth noting that an aerobic $\mathrm{Pd} / \mathrm{Cu}$-catalyzed cyclizative cross-coupling between 2-alkynylanilines and 2-alkynylbenzamides, affording indoles bearing an alkylideneiminoisobenzofurane moiety, has been reported [40].

\section{Results and Discussion}

The starting $N$-propargyl-2-iodobenzamides 2 were easily obtained by the reaction of the readily available [41] propargylamines 1 with 2-iodobenzoyl chloride in $\mathrm{CH}_{2} \mathrm{Cl}_{2}$ at room temperature (Scheme 2).

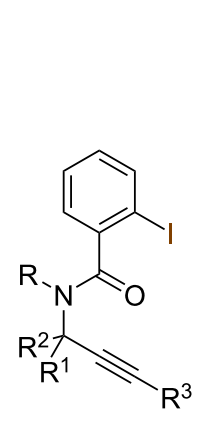

2

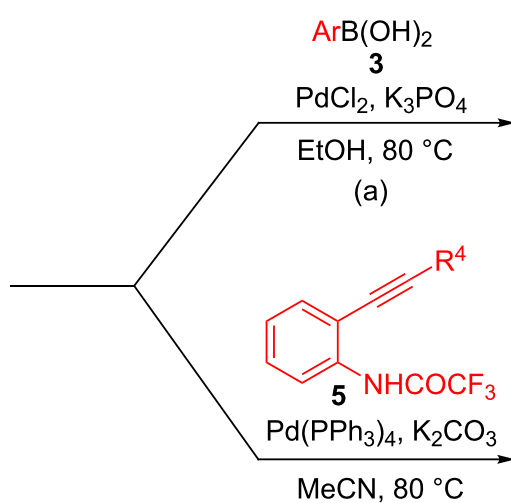

(b)<smiles>[R]C(Br)=C1c2ccccc2C(=O)N([R])C1([R])[R]</smiles><smiles>[R]C(=C1c2ccccc2C(=O)N([R])C1([R])[R])c1c([R])[nH]c2ccccc12</smiles>

6

Scheme 1: Planned approach to tetrasubstituted-4-methylene-3,4-dihydroisoquinolin-1(2H)-ones 4 and 6.<smiles>[R]NC([R])(C#C[R][Tl])C[Te]</smiles><smiles>O=C(Cl)c1ccccc1I</smiles>

1a-f<smiles>[R]C#CC(=O)N([R])C([R])c1ccccc1I</smiles>

2a-f 2a (83\%): $\mathrm{R}=\mathrm{CH}_{2} \mathrm{Ph} ; \mathrm{R}^{1}=\mathrm{R}^{2}=\mathrm{CH}_{3} ; \mathrm{R}^{3}=4-\mathrm{CH}_{3} \mathrm{CO}-\mathrm{C}_{6} \mathrm{H}_{4}$

2b (80\%): R = $\mathrm{CH}_{2} \mathrm{Ph} ; \mathrm{R}^{1}=\mathrm{R}^{2}=\mathrm{CH}_{3} ; \mathrm{R}^{3}=4-\mathrm{CH}_{3} \mathrm{O}-\mathrm{C}_{6} \mathrm{H}_{4}$

2c $(75 \%): R=\mathrm{CH}_{2} \mathrm{Ph} ; \mathrm{R}^{1}=\mathrm{R}^{2}=\mathrm{CH}_{3} ; \mathrm{R}^{3}=4-\mathrm{CF}_{3}-\mathrm{C}_{6} \mathrm{H}_{4}$

2d $(76 \%): \mathrm{R}=\mathrm{CH}_{2} \mathrm{Ph} ; \mathrm{R}^{1}=\mathrm{R}^{2}=\left(\mathrm{CH}_{2}\right)_{5} ; \mathrm{R}^{3}=\left(\mathrm{CH}_{2}\right)_{5}-\mathrm{CH}_{3}$

2e $(70 \%): R=\mathrm{CH}_{2} \mathrm{Ph} ; \mathrm{R}^{1}=\mathrm{Ph} ; \mathrm{R}^{2}=\mathrm{H} ; \mathrm{R}^{3}=\mathrm{Ph}$

2f $(70 \%): R=\mathrm{CH}_{2} \mathrm{Ph} ; \mathrm{R}^{1}=\mathrm{R}^{2}=\mathrm{H} ; \mathrm{R}^{3}=4-\mathrm{CH}_{3} \mathrm{CO}-\mathrm{C}_{6} \mathrm{H}_{4}$

Scheme 2: Preparation of the starting N-propargyl-2-iodobenzamides 2. 
Initially, we explored the reaction of the $N$-(4-(4-acetylphenyl)2-methylbut-3-yn-2-yl)- $N$-benzyl-2-iodobenzamide (2a) with a variable excess of the phenylboronic acid (3a) in the presence of $\mathrm{K}_{3} \mathrm{PO}_{4}$ as the base $\left(\mathrm{K}_{3} \mathrm{PO}_{4}: 3\right.$ equiv) by using $5 \mathrm{~mol} \%$ of different palladium catalysts/solvent/temperature combinations. The results are reported in Table 1.

When 1,4-dioxane was used as the solvent in the presence of commercially available $\mathrm{PdCl}_{2}\left(\mathrm{PPh}_{3}\right)_{2}$ as the catalyst at $100{ }^{\circ} \mathrm{C}$, the reaction of $\mathbf{2 a}$ with 1.5 equiv of the phenylboronic acid (3a) delivered the target $(\mathrm{Z})$-dihydroisoquinolin-1(2H)-one 4aa in $51 \%$ yield. Better yields were observed by increasing the excess of the phenylboronic acid (Table 1, entries 1-3) or by halving the amount of the solvent in the presence 1.5 equiv of $\mathbf{3 a}$ (Table 1, entry 4). Under these latter conditions a beneficial effect was obtained by using a 9:1 mixture of 1,4-dioxane/ $\mathrm{H}_{2} \mathrm{O}$ as the reaction medium (Table 1, entry 5). While MeCN, DMF, THF and DMSO as solvents gave worse results (Table 1, entries 6-9), the environmentally friendly EtOH proved to be the most efficient reaction medium (Table 1, entry 10). Further attempts to increase the yield of $\mathbf{4 a a}$ by tuning the catalytic system showed that the ligand-free $\mathrm{PdCl}_{2}$ was the most effective catalyst (Table 1, entry 14). Other catalysts such as $\mathrm{Pd}\left(\mathrm{PPh}_{3}\right)_{4}, \mathrm{Pd} / \mathrm{C}$ or $\mathrm{Pd}(\mathrm{OAc})_{2}$ provided inferior results (Table 1, entries 11-13).

We then examined the reaction of $\mathbf{2 a}$ with 1.5 equiv of a variety of arylboronic acids. Using the optimized reaction conditions of Table 1, entry 14, 2a reacted smoothly with diversely substituted arylboronic acids $\mathbf{3 a - i}$ to regio- and stereoselectively afford the corresponding tetrasubstituted 4-methylene-3,4-dihydroisoquinolin-1 $(2 H)$-ones $4 \mathbf{a b}-\mathbf{a i}$ in moderate to good yields (Scheme 3).

Gratifyingly, various functional groups such as amino, acetamido, $\mathrm{F}, \mathrm{Cl}, \mathrm{OMe}, \mathrm{CF}_{3}$, and $\mathrm{CN}$ moieties were found to be compatible with these reaction conditions, and only the homocoupling of the arylboronic acids was observed as side reaction to some extent [42]. The best results were obtained with aryl-

Table 1: Optimization of the reaction of propargyl 2-iodobenzamide $2 a$ with phenylboronic acid (3a). ${ }^{a}$<smiles>CC(=O)c1ccc(C#CC(C)(C)N(Cc2ccccc2)C(=O)c2ccccc2I)cc1</smiles>

$2 a$

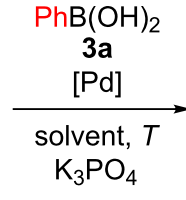<smiles></smiles>

4aa

\begin{tabular}{|c|c|c|c|c|c|}
\hline entry & solvent/temp. $\left({ }^{\circ} \mathrm{C}\right)$ & $3 a: 2 a$ ratio & catalyst & time $(\mathrm{h})$ & $\begin{array}{l}\text { 4aa } \\
\text { yield }(\%)^{b}\end{array}$ \\
\hline 1 & dioxane/100 & 1.5 & $\mathrm{PdCl}_{2}\left(\mathrm{PPh}_{3}\right)_{2}$ & 7 & 51 \\
\hline 2 & dioxane/100 & 2.0 & $\mathrm{PdCl}_{2}\left(\mathrm{PPh}_{3}\right)_{2}$ & 2 & 94 \\
\hline 3 & dioxane/100 & 3.0 & $\mathrm{PdCl}_{2}\left(\mathrm{PPh}_{3}\right)_{2}$ & 2 & 97 \\
\hline 4 & dioxane/100 & 1.5 & $\mathrm{PdCl}_{2}\left(\mathrm{PPh}_{3}\right)_{2}$ & 4 & $67^{c}$ \\
\hline 5 & dioxane/water $(9: 1) / 100$ & 1.5 & $\mathrm{PdCl}_{2}\left(\mathrm{PPh}_{3}\right)_{2}$ & 2 & $80^{c}$ \\
\hline 6 & $\mathrm{MeCN} / 80$ & 1.5 & $\mathrm{PdCl}_{2}\left(\mathrm{PPh}_{3}\right)_{2}$ & 7 & $41^{c}$ \\
\hline 7 & $\mathrm{THF} / 60$ & 1.5 & $\mathrm{PdCl}_{2}\left(\mathrm{PPh}_{3}\right)_{2}$ & 7 & $27^{c}$ \\
\hline 8 & $\mathrm{DMF} / 110$ & 1.5 & $\mathrm{PdCl}_{2}\left(\mathrm{PPh}_{3}\right)_{2}$ & 2.5 & $58^{c}$ \\
\hline 9 & DMSO/110 & 1.5 & $\mathrm{PdCl}_{2}\left(\mathrm{PPh}_{3}\right)_{2}$ & 2.5 & $41^{c}$ \\
\hline 10 & $\mathrm{EtOH} / 80$ & 1.5 & $\mathrm{PdCl}_{2}\left(\mathrm{PPh}_{3}\right)_{2}$ & 3 & $85^{c}$ \\
\hline 11 & $\mathrm{EtOH} / 80$ & 1.5 & $\mathrm{Pd}\left(\mathrm{PPh}_{3}\right)_{4}$ & 3 & $74^{c}$ \\
\hline 12 & $\mathrm{EtOH} / 80$ & 1.5 & $\mathrm{Pd} / \mathrm{C}$ & 3 & $66^{c}$ \\
\hline 13 & $\mathrm{EtOH} / 80$ & 1.5 & $\mathrm{Pd}(\mathrm{OAc})_{2}$ & 2.5 & $77^{\mathrm{C}}$ \\
\hline 14 & EtOH/80 & 1.5 & $\mathrm{PdCl}_{2}$ & 2.5 & $91^{c}$ \\
\hline
\end{tabular}

a Reactions were carried out on a $0.19 \mathrm{mmol}$ scale, using 3 equiv of base, 0.10 equiv of ligand and 0.05 equiv of the palladium catalyst in $2.0 \mathrm{~mL}$ of solvent under nitrogen atmosphere. ${ }^{b}$ Yields are given for isolated products. ${ }^{c} 1.0 \mathrm{~mL}$ of solvent. 


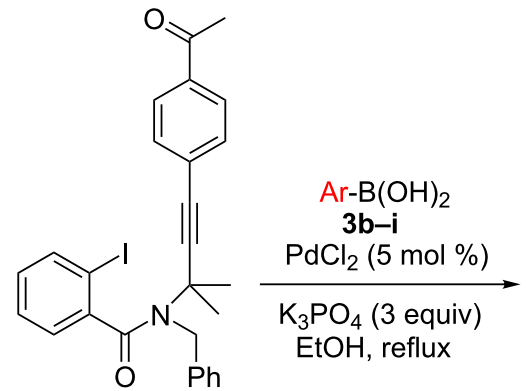

2a<smiles>CC(=O)c1ccc(/C(Br)=C2/c3ccccc3C(=O)N(Cc3ccccc3)C2(C)C)cc1</smiles>

4ab-ai

\begin{tabular}{|c|c|}
\hline $\mathrm{Ar}=$ & 3 \\
\hline 3- $\mathrm{CH}_{3} \mathrm{O}-\mathrm{C}_{6} \mathrm{H}_{4}$ & \\
\hline $\begin{array}{l}4-\mathrm{F}_{-} \mathrm{C}_{6} \mathrm{H}_{4} \\
3-\mathrm{CH}_{3} \mathrm{CONH}-\mathrm{C}_{6} \mathrm{H}_{4}\end{array}$ & \\
\hline $\begin{array}{l}3-\mathrm{CH}_{3} \mathrm{CONH}-\mathrm{C}_{6} \mathrm{H}_{4} \\
4-\left(\mathrm{CH}_{3}\right)_{2} \mathrm{~N}-\mathrm{C}_{6} \mathrm{H}_{4}\end{array}$ & \\
\hline 3,5-dimethylphenyl & \\
\hline $3-\mathrm{CN}-\mathrm{C}_{6} \mathrm{H}_{4}$ & \\
\hline $3-\mathrm{CF}_{3}-\mathrm{C}_{6} \mathrm{H}_{4}$ & \\
\hline $3-\mathrm{Cl}-4-\mathrm{F}-\mathrm{C}_{6} \mathrm{H}_{3}$ & \\
\hline
\end{tabular}<smiles>COc1cccc(C(=C2C(=O)c3ccccc3C(C)(C)N2Cc2ccccc2)c2ccc(C(C)=O)cc2)c1</smiles>

4ab $(84 \%, 2.5 \mathrm{~h})$<smiles>CC(=O)c1ccc(C(=C2C(=O)c3ccccc3C(c3ccc(F)cc3)=C2C)C(C)(C)CNc2ccccc2)cc1</smiles>

4ac $(76 \%, 3.0 \mathrm{~h})$<smiles>CC(=O)Nc1cccc(C(=C2C(=O)c3ccccc3C(=O)N2Cc2ccccc2)c2ccc(C(C)=O)cc2)c1</smiles>

4ad $(85 \%, 2.5 \mathrm{~h})$<smiles>CCN(CC)c1ccc(C(=C2c3ccccc3C(=O)N(Cc3ccccc3)C2(C)C)c2ccc(C(C)=O)cc2)cc1</smiles>

4ae $(88 \%, 2.5 \mathrm{~h})$<smiles>CC(=O)c1ccc(C(=C2c3ccccc3C(=O)N(Cc3ccccc3)C2(C)C)c2cc(C)cc(C)c2)cc1</smiles>

4af $(78 \%, 2.5 \mathrm{~h})$<smiles>CC(=O)c1ccc(C(=C2C(=O)c3ccccc3C2(C)C)c2cccc(C#N)c2)cc1</smiles>

4ag $(57 \%, 3.0 \mathrm{~h})$<smiles>CC(=O)c1ccc(C(=C2c3ccccc3C(=O)N(Cc3ccccc3)C2(C)C)c2cccc(C(F)(F)F)c2)cc1</smiles>

4ah $(61 \%, 3.0 \mathrm{~h})$<smiles>CC(=O)c1ccc(C(=C2C(=O)c3ccccc3C2(C)C)c2ccc(F)c(Cl)c2)cc1</smiles>

4ai $(68 \%, 4.5 \mathrm{~h})$

Scheme 3: Substrate scope of the reaction of $N$-propargyl-2-iodobenzamide $2 \mathbf{a}$ with arylboronic acids $\mathbf{3 b}$-i.

boronic acids containing electron-donating substituents; electron-poor arylboronic acids proved to be slightly less effective, probably because of their lower nucleophilicity that could have affected the transmetalation step.

Moreover, we screened the reaction of a number of aromatic boronic acids $\mathbf{3 a}-\mathbf{j}$ with a set of $N$-propargyl-2-iodobenzamides 2c-f (Scheme 4).

All reactions successfully delivered the desired products $\mathbf{4}$ in moderate to good yields. Remarkably, an alkyl substituent was tolerated at the terminal sp carbon atom of the starting $\mathrm{N}$-propargyl-2-iodobenzamides 2. Furthermore, 2-iodobenzamides $2 \mathbf{e}$ and $\mathbf{2 f}$ (mono-substituted and unsubstituted at the propargylic position) were successfully used as starting materials, affording the corresponding products $\mathbf{4 e b}, \mathbf{4 f c}$ and $\mathbf{4 f j}$ in good yields. According to the literature, the highly stereoselective formation of products $\mathbf{4}$ resulted from the intramolecular syn-addition of the in situ-generated arylpalladium iodide complex to the triple bond to give an $(E)$-vinylpalladium intermediate, which underwent cross-coupling with an arylboronic acid leading to the final product by reductive elimination, with the regeneration of the $\operatorname{Pd}(0)$ catalyst.

Finally, we envisaged that the above mentioned $(E)$-vinylpalladium intermediate $\mathbf{A}$ (generated in situ from the insertion of a carbon-carbon triple bond in the initially formed arylpalladium complex) could also be involved in the aminopalladations with the alkynyltrifluoroacetanilides $\mathbf{5}$ through the formation of the $\pi$-complex $\mathbf{B}$, followed by base-assisted cyclization and reductive elimination from the resulting $\sigma$-indolylpalladium complex C (Scheme 5). 


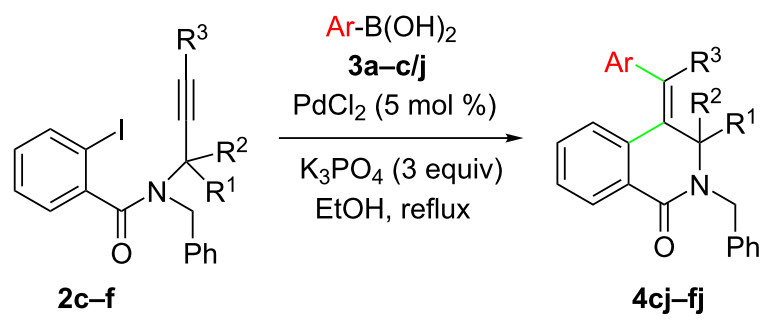

$\left(\mathbf{3} \mathbf{j}=4-\mathrm{CH}_{3} \mathrm{O}-\mathrm{C}_{6} \mathrm{H}_{4}-\mathrm{B}(\mathrm{OH})_{2}\right)$<smiles>COc1ccc(C(=C2C(=CC(=O)c3ccccc3)C(=O)N(Cc3ccccc3)C2(C)C)c2ccc(C(F)(F)F)cc2)cc1</smiles>

4cj $(95 \%, 2.0 \mathrm{~h})$<smiles>COc1cccc(C(=C2c3ccccc3C(=O)N(Cc3ccccc3)C2c2ccccc2)c2ccccc2)c1</smiles>

4eb $(88 \%, 2.0 \mathrm{~h})$<smiles>CCCCCC/C(=C1/c2ccccc2C(=O)N(Cc2ccccc2)C12CCCCC2)c1ccccc1</smiles>

4da $(52 \%, 2.0 \mathrm{~h})$<smiles>CCCCCC/C(=C1/c2ccccc2C(=O)N(Cc2ccccc2)C12CCCCC2)c1cccc(OC)c1</smiles>

$4 \mathrm{db}(56 \%, 2.0 \mathrm{~h})$<smiles>CC(=O)c1ccc(C(=C2CN(Cc3ccccc3)C(=O)c3ccccc32)c2ccc(F)cc2)cc1</smiles>

4fc $(80 \%, 3.0 \mathrm{~h})$<smiles>COc1ccc(C(=C2CN(Cc3ccccc3)C(=O)c3ccccc32)c2ccc(C(C)=O)cc2)cc1</smiles>

4fj $(92 \%, 2.0 \mathrm{~h})$

Scheme 4: Substrate scope of the reaction of $N$-propargyl-2-iodobenzamides $2 \mathrm{c}-\mathbf{f}$ with arylboronic acids $3 \mathbf{a}-\mathbf{c} / \mathbf{j}$.

The reaction led to the stereoselective formation of indole derivatives 6ba-fc (aryl, heteroaryl and vinyl groups were allowed in substrates 5) in good to high yield.

The stereochemistry of compounds $\mathbf{4}$ and $\mathbf{6}$ was unambiguously confirmed by NMR spectroscopy [43].

\section{Conclusion}

In conclusion, we have demonstrated that cascade cyclocarbopalladations of the readily available aryl/alkyl-substituted $\mathrm{N}$-propargyl-2-iodobenzamides 2 followed by Suzuki-Miyaura coupling reactions with arylboronic acids, in the presence of a catalytic amount of the ligand-free $\mathrm{PdCl}_{2}$ in environmentally friendly ethanol, achieve an efficient regio- and stereoselective synthesis of 4-methylene-3,4-dihydroisoquinolin-1(2H)-ones 4. It is worth noting that, during the preparation of this paper, a related article focused on the palladium-catalyzed regioselective cascade cyclization of propargylamides/coupling with
$\mathrm{ArB}(\mathrm{OH})_{2}$ in dioxane/water, to give trisubstituted arylideneisoquinolinones [44] was published. However, the Ugi fourcomponent reaction used to construct the starting building blocks was limited to the preparation of propargylic 2-halobenzamides unsubstituted at the propargyl carbon, allowing the synthesis of isoquinolinones without substituents at C-3; but the present methodology overcame these limitations.

Moreover, the previously developed strategy of indole synthesis through an aminopalladation/reductive elimination process has been significantly extended to include $\sigma$-vinyl $\mathrm{Pd}(\mathrm{II})$ intermediates $\mathbf{B}$ obtained through oxidative addition/insertion of substrates 2 with $\operatorname{Pd}(0)$. This reaction efficiently led to challenging indoloquinolinones $\mathbf{6}$ through a sequential double cyclization. It is worth noting that, in both cases, the intramolecular alkyne insertion in the initially formed arylpalladium iodide $\mathbf{A}$ (leading to $\mathbf{B}$ ) occured faster than the direct reaction of $\mathbf{A}$ with arylboronic acids or with 2-alkynyltrifluoroacetanilides. 


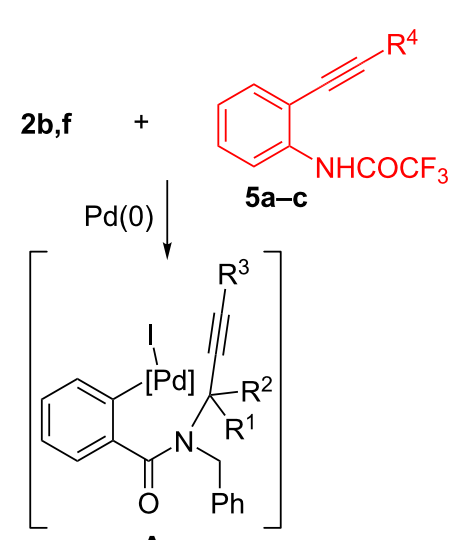<smiles>[R]/C(=C1\c2ccccc2C(=O)N(Cc2ccccc2)C1([R1])[R])c1c([R])[nH]c2ccccc12</smiles><smiles>CC[CH-]F</smiles>

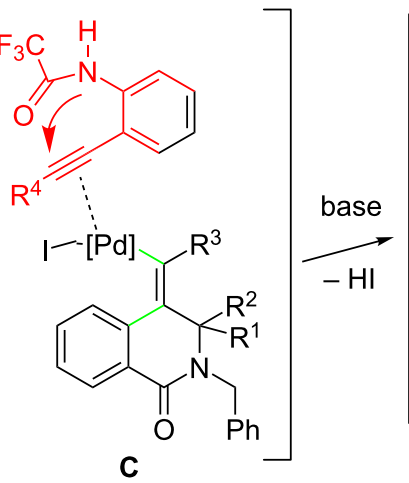

6ba-6fc<smiles>CC(C)O</smiles>

A $\downarrow$ insertion

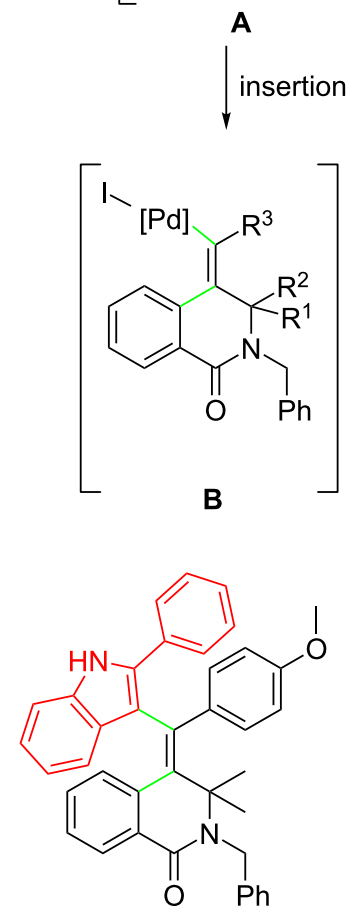

6ba $(70 \%, 3 \mathrm{~h})$<smiles>CC(=O)c1ccc(C(=C2CN(Cc3ccccc3)C(=O)c3ccccc32)c2ccccc2-c2ccccc2)cc1</smiles>

$6 f a(89 \%, 1 \mathrm{~h})$<smiles>CC(=O)c1ccc(C(=C2CN(Cc3ccccc3)C(=O)c3ccccc32)c2c(-c3cccs3)[nH]c3ccccc23)cc1</smiles>

$6 \mathrm{fb}(83 \%, 1 \mathrm{~h})$<smiles>CC(=O)c1ccc(C(=C2CN(Cc3ccccc3)C(=O)c3ccccc32)c2c(C3=CCCCCCC3)[nH]c3ccccc23)cc1</smiles>

6fc $(79 \%, 1 \mathrm{~h})$

Scheme 5: Reaction of $N$-propargyl-2-iodobenzamides $\mathbf{2 b}$,f with the 2-alkynyltrifluoroacetanilides 5a-c.

\section{Experimental}

\section{General methods}

Melting points are uncorrected. IR spectra were recorded with a Perkin Elmer Spectrum Two FT/IR spectrometer. ${ }^{1} \mathrm{H}$ NMR spectra were recorded in $\mathrm{CDCl}_{3}$ at $400 \mathrm{MHz}$ on Bruker Avance 400 instrument. Chemical shifts (in ppm) were referenced to tetramethylsilane $(\delta=0 \mathrm{ppm})$ as an internal standard. ${ }^{13} \mathrm{C} \mathrm{NMR}$ spectra were recorded in $\mathrm{CDCl}_{3}$ at $100.6 \mathrm{MHz}$ and were calibrated with $\mathrm{CDCl}_{3}(\delta=77.00 \mathrm{ppm})$ or tetramethylsilane $(\delta=0 \mathrm{ppm})$. Mass spectrometry was performed using a MALDI-TOF spectrometer AB SCIEX TOF/TOF 5800 system using 3-hydroxycoumarin or $\alpha$-cyano-4-hydroxycinnamic acid as a matrix in combination with KI for the ionization. Unless otherwise stated, all starting materials, catalysts, and solvents were commercially available and were used as purchased. The reaction products were purified by flash chromatography on silica gel by elution with $n$-hexane/EtOAc mixtures. Compounds 1a [44], 1b,c [41], 1d [45], 1e [46] and 5a-c [47] are known products and were identified by comparison of their physical and spectral data obtained with those reported in the cited references.

\section{Procedures}

Procedure for the preparation of 1-(4-(3-(benzylamino)prop-1-yn-1-yl)phenyl)ethanone (1f): To a solution of $N$-benzylprop-2-yn-1-amine $(0.25 \mathrm{~g}, 1,72 \mathrm{mmol})$ in $3 \mathrm{~mL}$ of an- 
hydrous THF were added diisopropylamine $(1.2 \mathrm{~mL}$, $8.6 \mathrm{mmol})$, 4-iodoacetophenone (0.505 g, $2.06 \mathrm{mmol})$, $\mathrm{PdCl}_{2}\left(\mathrm{PPh}_{3}\right)_{2}(18,1 \mathrm{mg}, 0.026 \mathrm{mmol})$ and $\mathrm{CuI}(9.8 \mathrm{mg}$, $0.051 \mathrm{mmol})$. The mixture was stirred at room temperature under an $\mathrm{N}_{2}$ atmosphere for 2 hours. Then the reaction mixture was diluted with ethyl acetate, washed with a solution of $\mathrm{NH}_{4} \mathrm{Cl}$ $0.5 \mathrm{M}$, dried over $\mathrm{Na}_{2} \mathrm{SO}_{4}$ and concentrated under reduced pressure. The residue was purified by flash chromatography (silica gel, $n$-hexane/EtOAc, 65:35 v/v) to afford 1-(4-(3-(benzylamino)prop-1-yn-1-yl)phenyl)ethanone (1f, $385.0 \mathrm{mg}, 85 \%$ ).

Typical procedure for the preparation of $N$-benzyl-2iodobenzamides $(2 \mathbf{a}-\mathbf{f})$ : To a solution $(0.25 \mathrm{M})$ of the propargylamine 1 (1 equiv) [48] in anhydrous dichloromethane $(5 \mathrm{~mL})$ were added at room temperature, under $\mathrm{N}_{2}$ atmosphere, 2-iodobenzoyl chloride ( 1.5 equiv) and anhydrous triethylamine ( 2 equiv). The reaction mixture was stirred under $\mathrm{N}_{2}$ until complete consumption of the starting propargylamine (monitored by TLC). Then the reaction mixture was diluted with ethyl acetate, washed with a solution of $\mathrm{NH}_{4} \mathrm{Cl}(0.5 \mathrm{M})$, dried over $\mathrm{Na}_{2} \mathrm{SO}_{4}$ and concentrated under reduced pressure. The residue was purified by flash chromatography (silica gel, $n$-hexane/EtOAc) to afford the $N$-benzyl-2-iodobenzamide 2.

Typical procedure for the preparation of-2-benzyl-3,4-dihydroisoquinolin-1 $(2 H)$-ones $(4)$ : preparation of $(\mathrm{Z})-4-((4-$ acetylphenyl)(phenyl)methylene)-2-benzyl-3,3-dimethyl-3,4dihydroisoquinolin-1(2H)-one (4aa): To a stirred solution $(0.2 \mathrm{M})$ of $\mathrm{N}$-(4-(4-acetylphenyl)-2-methylbut-3-yn-2-yl)- $\mathrm{N}$ benzyl-2-iodobenzamide (2a, $100 \mathrm{mg}, 0.19 \mathrm{mmol})$ in $\mathrm{EtOH}$ (1 mL), were added phenylboronic acid (3a, $34.7 \mathrm{mg}$, $0.285 \mathrm{mmol}$ ) and $\mathrm{K}_{3} \mathrm{PO}_{4}(120.9 \mathrm{mg}, 0.57 \mathrm{mmol})$; after $5 \mathrm{~min}$ stirring at room temperature, $\mathrm{PdCl}_{2}(2 \mathrm{mg}, 0.0095 \mathrm{mmol})$ was added. The mixture was stirred at $79{ }^{\circ} \mathrm{C}$ under an $\mathrm{N}_{2}$ atmosphere and stirring was continued at that temperature until complete consumption of the starting propargylamide $\mathbf{2 a}$ (monitored by TLC). Then the reaction mixture was cooled to room temperature, diluted with ethyl acetate (EtOAc), washed with a solution of $\mathrm{NH}_{4} \mathrm{Cl}(0.5 \mathrm{M})$, dried over $\mathrm{Na}_{2} \mathrm{SO}_{4}$ and concentrated under reduced pressure. The residue was purified by flash chromatography (silica gel, $n$-hexane/EtOAc, 70:30 v/v) to afford the dihydroisoquinolin-1(2H)-one 4aa.

General procedure for the preparation of indole-substituted dihydroisoquinolin-1 $(2 H)$-ones 6: To a stirred solution of propargylamide $2(0.1 \mathrm{mmol})$ in $\mathrm{MeCN}(2 \mathrm{~mL})$ were added 2-alkynyltrifluoroacetylanilide $5(0.12 \mathrm{mmol})$ and $\mathrm{K}_{2} \mathrm{CO}_{3}$ $(0.3 \mathrm{mmol})$; after $5 \mathrm{~min}$ stirring at room temperature $\mathrm{Pd}\left(\mathrm{PPh}_{3}\right)_{4}$ $(0.005 \mathrm{mmol})$ was added. The mixture was stirred at $80{ }^{\circ} \mathrm{C}$ under $\mathrm{N}_{2}$ atmosphere until complete consumption of the starting propargylamide (monitored by TLC). Then the reaction mix- ture was cooled to room temperature, diluted with ethyl acetate, washed with a $0.5 \mathrm{M}$ solution of $\mathrm{NH}_{4} \mathrm{Cl}$, dried over $\mathrm{Na}_{2} \mathrm{SO}_{4}$ and concentrated under reduced pressure. The residue was purified by flash chromatography (silica gel, $n$-hexane/EtOAc, $80: 20-50: 50 \mathrm{v} / \mathrm{v}$ ) to afford the desired dihydroisoquinolin$1(2 H)$-one 6.

\section{Supporting Information}

\section{Supporting Information File 1}

Characterization of all new compounds, copies of ${ }^{1} \mathrm{H}$ and

${ }^{13} \mathrm{C}$ NMR spectra, 2D NOESY experiments.

[https://www.beilstein-journals.org/bjoc/content/

supplementary/1860-5397-16-95-S1.pdf]

\section{Funding}

We gratefully acknowledge the University of L'Aquila for financial support.

\section{ORCID ${ }^{\circledR}$ iDs}

Valeria Nori - https://orcid.org/0000-0002-6634-1620 Antonio Arcadi - https://orcid.org/0000-0001-9053-648X

Armando Carlone - https://orcid.org/0000-0003-2983-6445

Fabio Marinelli - https://orcid.org/0000-0001-5368-1098

Marco Chiarini - https://orcid.org/0000-0002-2298-5467

\section{Preprint}

A non-peer-reviewed version of this article has been previously published as a preprint doi:10.3762/bxiv.2020.8.v1

\section{References}

1. Pettit, G. R.; Meng, Y.; Herald, D. L.; Graham, K. A. N.; Pettit, R. K.; Doubek, D. L. J. Nat. Prod. 2003, 66, 1065-1069. doi:10.1021/np0300986

2. Glushkov, V. A.; Shklyaev, Y. V. Chem. Heterocycl. Compd. 2001, 37, 663-687. doi:10.1023/a:1011958810129

3. Jin, Z. Nat. Prod. Rep. 2013, 30, 849-868. doi:10.1039/c3np70005d

4. Bhadra, K.; Suresh Kumar, G. Mini-Rev. Med. Chem. 2010, 10, 1235-1247. doi:10.2174/13895575110091235

5. Giri, P.; Suresh Kumar, G. Mini-Rev. Med. Chem. 2010, 10, 568-577. doi:10.2174/138955710791384009

6. Ruchelman, A. L.; Houghton, P. J.; Zhou, N.; Liu, A.; Liu, L. F.; LaVoie, E. J. J. Med. Chem. 2005, 48, 792-804. doi:10.1021/jm049447z

7. Saeed, A.; Ashraf, Z. Pharm. Chem. J. 2008, 42, 277-280. doi:10.1007/s11094-008-0105-y

8. Guastavino, J. F.; Barolo, S. M.; Rossi, R. A. Eur. J. Org. Chem. 2006, 3898-3902. doi:10.1002/ejoc.200600244

9. Matsui, T.; Sugiura, T.; Nakai, H.; Iguchi, S.; Shigeoka, S.; Takada, H.; Odagaki, Y.; Nagao, Y.; Ushio, Y.; Ohmoto, K.; Iwamura, H.; Yamazaki, S.; Arai, Y.; Kawamura, M. J. Med. Chem. 1992, 35, 3307-3319. doi:10.1021/jm00096a001 
10. Plettenburg, O.; Lorenz, K.; Goerlitzer, J.; Löhn, M. Substituted isoquinolines and their use as rho-kinase inhibitors. WO Patent WO2008077555A2, July 3, 2008.

11. Li, S. W.; Nair, M. G.; Edwards, D. M.; Kisliuk, R. L.; Gaumont, Y.; Dev, I. K.; Duch, D. S.; Humphreys, J.; Smith, G. K.; Ferone, R. J. Med. Chem. 1991, 34, 2746-2754. doi:10.1021/jm00113a011

12. Vinod, K. R.; Chandra, S.; Sharma, S. K. Toxicol. Mech. Methods 2010, 20, 90-95. doi:10.3109/15376510903572870

13. Hudlicky, T.; Rinner, U.; Gonzalez, D.; Akgun, H.; Schilling, S.; Siengalewicz, P.; Martinot, T. A.; Pettit, G. R. J. Org. Chem. 2002, 67, 8726-8743. doi:10.1021/j0020129m

14. Francis, S.; Croft, D.; Schüttelkopf, A. W.; Parry, C.; Pugliese, A.; Cameron, K.; Claydon, S.; Drysdale, M.; Gardner, C.; Gohlke, A. Goodwin, G.; Gray, C. H.; Konczal, J.; McDonald, L.; Mezna, M.; Pannifer, A.; Paul, N. R.; Machesky, L.; McKinnon, H.; Bower, J. Bioorg. Med. Chem. Lett. 2019, 29, 1023-1029. doi:10.1016/j.bmcl.2019.01.035

15. Takwale, A. D.; Jeon, Y. U.; Lee, D. H.; Kim, H. J.; Hwang, J. Y. Tetrahedron Lett. 2019, 60, 1259-1261. doi:10.1016/j.tetlet.2019.03.073

16. Beng, T. K.; Langevin, S.; Farah, A. O.; Goodsell, J.; Wyatt, K. New J. Chem. 2019, 43, 5282-5286. doi:10.1039/c8nj06539j

17. Xie, H.; Xing, Q.; Shan, Z.; Xiao, F.; Deng, G.-J. Adv. Synth. Catal. 2019, 361, 1896-1901. doi:10.1002/adsc.201801635

18. Yang, Z.; Jie, L.; Yao, Z.; Yang, Z.; Cui, X. Adv. Synth. Catal. 2019, 361, 214-218. doi:10.1002/adsc.201801217

19. Ma, S. Handbook of Cyclization Reactions; Wiley-VCH: Weinheim, Germany, 2010; Vol. 1.

20. Sperger, T.; Le, C. M.; Lautens, M.; Schoenebeck, F. Chem. Sci. 2017, 8, 2914-2922. doi:10.1039/c6sc05001h

21. Blouin, S.; Gandon, V.; Blond, G.; Suffert, J. Angew. Chem., Int. Ed. 2016, 55, 7208-7211. doi:10.1002/anie.201602586

22. Le, C. M.; Hou, X.; Sperger, T.; Schoenebeck, F.; Lautens, M. Angew. Chem., Int. Ed. 2015, 54, 15897-15900. doi:10.1002/anie.201507883

23. Milde, B.; Leibeling, M.; Pawliczek, M.; Grunenberg, J.; Jones, P. G.; Werz, D. B. Angew. Chem., Int. Ed. 2015, 54, 1331-1335. doi:10.1002/anie.201408637

24. Kan, S. B. J.; Anderson, E. A. Org. Lett. 2008, 10, 2323-2326. doi:10.1021/ol8007952

25. Bour, C.; Blond, G.; Salem, B.; Suffert, J. Tetrahedron 2006, 62, 10567-10581. doi:10.1016/j.tet.2006.06.116

26. Düfert, A.; Werz, D. B. Chem. - Eur. J. 2016, 22, 16718-16732. doi:10.1002/chem.201603044

27. Peshkov, A. A.; Peshkov, V. A.; Pereshivko, O. P.; Van Hecke, K.; Kumar, R.; Van der Eycken, E. V. J. Org. Chem. 2015, 80, 6598-6608. doi:10.1021/acs.joc.5b00670

28. Nandakumar, A.; Perumal, P. T. Org. Lett. 2013, 15, 382-385. doi:10.1021/ol303326g

29. Charpenay, M.; Boudhar, A.; Siby, A.; Schigand, S.; Blond, G.; Suffert, J. Adv. Synth. Catal. 2011, 353, 3151-3156. doi:10.1002/adsc.201100465

30. Richey, R. N.; Yu, H. Org. Process Res. Dev. 2009, 13, 315-320. doi:10.1021/op800231b

31. Mondal, A.; Kundu, P.; Jash, M.; Chowdhury, C. Org. Biomol. Chem. 2018, 16, 963-980. doi:10.1039/c7ob02788e

32. Arcadi, A.; Blesi, F.; Cacchi, S.; Fabrizi, G.; Goggiamani, A.; Marinelli, F. J. Org. Chem. 2013, 78, 4490-4498. doi:10.1021/jo400503f
33. Arcadi, A.; Cacchi, S.; Fabrizi, G.; Goggiamani, A.; lazzetti, A.; Marinelli, F. Org. Biomol. Chem. 2013, 11, 545-548. doi:10.1039/c2ob27125g

34. He, Y.-P.; Wu, H.; Wang, Q.; Zhu, J. Angew. Chem., Int. Ed. 2020, 59, 2105-2109. doi:10.1002/anie.201914049

35. Arcadi, A.; Cacchi, S.; Marinelli, F. Tetrahedron Lett. 1992, 33, 3915-3918. doi:10.1016/s0040-4039(00)74818-0

36. Cacchi, S.; Fabrizi, G.; Lamba, D.; Marinelli, F.; Parisi, L. M. Synthesis 2003, 728-734. doi:10.1055/s-2003-38079

37. Arcadi, A.; Cacchi, S.; Fabrizi, G.; Marinelli, F. Synlett 2000, 394-396. doi:10.1055/s-2000-6529

38. Arcadi, A.; Cacchi, S.; Fabrizi, G.; Marinelli, F.; Parisi, L. M. J. Org. Chem. 2005, 70, 6213-6217. doi:10.1021/jo050517z

39. Arcadi, A.; Cianci, R.; Ferrara, G.; Marinelli, F. Tetrahedron 2010, 66, 2378-2383. doi:10.1016/j.tet.2010.01.096

40. Yao, B.; Wang, Q.; Zhu, J. Angew. Chem., Int. Ed. 2013, 52, 12992-12996. doi:10.1002/anie.201307738

41. Arcadi, A.; Aschi, M.; Chiarini, M.; Ferrara, G.; Marinelli, F. Adv. Synth. Catal. 2010, 352, 493-498. doi:10.1002/adsc.200900773

42. Ostrowska, S.; Rogalski, S.; Lorkowski, J.; Walkowiak, J.; Pietraszuk, C. Synlett 2018, 29, 1735-1740. doi:10.1055/s-0036-1591602

43. The double bond configurations of $4 \mathrm{fj}$ and $6 \mathrm{fa}$, as model of compounds, were unambiguously assigned as $E$-isomer by ${ }^{1} \mathrm{H}$ NOESY spectroscopy. NOESY was recorded using standard Bruker pulse sequences and mixing time of $800 \mathrm{~ms}$. See the section for 2D spectra in Supporting Information File 1.

44. Asgari, M. S.; Mirzazadeh, R.; Larijani, B.; Rashidi Ranjbar, P.; Rahimi, R.; Mahdavi, M. Synlett 2019, 30, 1073-1076. doi:10.1055/s-0037-1611804

45. Pierce, C. J.; Larsen, C. H. Green Chem. 2012, 14, 2672-2676. doi:10.1039/c2gc35713e

46. Ranjan, A.; Deore, A. S.; Yerande, S. G.; Dethe, D. H. Eur. J. Org. Chem. 2017, 4130-4139. doi:10.1002/ejoc.201700603

47. Arcadi, A.; Cacchi, S.; Carnicelli, V.; Marinelli, F. Tetrahedron 1994, 50, 437-452. doi:10.1016/s0040-4020(01)80766-3

48. Montgomery, S. L.; Mangas-Sanchez, J.; Thompson, M. P.; Aleku, G. A.; Dominguez, B.; Turner, N. J. Angew. Chem., Int. Ed. 2017, 56, 10491-10494. doi:10.1002/anie.201705848

\section{License and Terms}

This is an Open Access article under the terms of the Creative Commons Attribution License (http://creativecommons.org/licenses/by/4.0). Please note that the reuse, redistribution and reproduction in particular requires that the authors and source are credited.

The license is subject to the Beilstein Journal of Organic Chemistry terms and conditions: (https://www.beilstein-journals.org/bjoc)

The definitive version of this article is the electronic one which can be found at: doi: $10.3762 /$ bjoc. 16.95 